\title{
PENDIDIKAN PEACE BUILDING DI PESANTREN: Sebuah Upaya Mencegah Radikalisasi
}

\author{
Laily Fitriani \\ UIN Maulana Malik Ibrahim Malang \\ Email: fitrianilaily@gmail.com
}

\begin{abstract}
Islamic boarding school applying a principle of tasamuh (tolerant), tawassuth wal i'tidal (simple), tawazun (consideration) and ukhuwah (brotherhood). Islamic boarding school has a very strategic role in transforming peace culture through peace building education. The phenomenon of radicalism that led to violence in the next years will continue to be a threat and challenge religious tolerance in Indonesia.Therefore, presenting a religious understanding of non-violence with all wisdom values of boarding school education perhaps an attempt to establish the normative theological awareness and social consciousness, where we live in a pluralistic society in terms of religion, culture, ethnicity and various other social diversity. Pesantren as a place to train Muslim generations needs to transfer the peace as a form of Islam as rahmatan lil'Alamin, both to other Muslims and society so there is no longer any conflict driven by pesantren. The whole understanding of Islam makes the pesantren community has always spread the values of humanity and peace.
\end{abstract}

Pondok pesantren menerapkan prinsip tasamuh (toleran), tawasuth wal i'tidal (sederhana), tawazun (penuh pertimbangan) dan ukhuwah (persaudaraan). Peran pesantren sangat strategis dalam mentransformasikan budaya damai melalui pendidikan peace building. Fenomena radikalisme yang berujung pada aksi kekerasan kemungkinan di tahun-tahun mendatang akan terus menjadi ancaman sekaligus tantangan toleransi agama-agama di Indonesia. Karenanya, menghadirkan pemahaman keagamaan anti kekerasan dengan segenap nilainilai kearifan pendidikan kepesantrenan barangkali sebuah upaya untuk membangun kesadaran normatif teologis dan juga kesadaran sosial, dimana 
kita hidup di tengah masyarakat yang plural dari segi agama, budaya, etnis, dan berbagai keragaman sosial lainnya. Pesantren sebagai wadah menggembleng generasi muslim perlu melakukan transfer perdamaian sebagai wujud Islam sebagai rahmatan lil 'alamin, baik kepada sesama muslim dan masyarakat sehingga tidak ada lagi kasus konflik yang dimotori oleh pesantren. Pemahaman Islam yang utuh membuat komunitas pesantren selalu menebarkan nilai-nilai kemanusiaan dan perdamaian.

Keywords: boarding school, radicalism.

\section{Pendahuluan}

Munculnya isu-isu politis mengenai radikalisme Islam merupakan tantangan baru bagi umat Islam untuk menjawabnya. Isu radikalisme Islam ini sebenarnya sudah lama mencuat di permukaan wacana internasional. Radikalisme Islam sebagai fenomena historis-sosiologis merupakan masalah yang banyak dibicarakan dalam wacana politik dan peradaban global akibat kekuatan media yang memiliki potensi besar dalam menciptakan persepsi masyarakat dunia. Banyak label-label yang diberikan oleh kalangan Eropa Barat dan Amerika Serikat untuk menyebut gerakan Islam radikal, dari sebutan kelompok garis keras, ekstrimis, militan, Islam kanan, fundamentalisme sampai terorisme.

Di negara-negara barat pasca hancurnya ideologi komunisme (pasca perang dingin) memandang Islam sebagai sebuah gerakan dari peradaban yang menakutkan. Tidak ada gejolak politik yang lebih ditakuti melebihi bangkitnya gerakan Islam yang diberinya label sebagai radikalisme Islam. Tuduhan-tuduhan dan propaganda Barat atas Islam sebagai agama yang menopang gerakan radikalisme telah menjadi retorika internasional (Bahri, 2004: 2).

Agama dilihat sebagai sistem kepercayaan yang mencerminkan kekuatan moral baik secara individu maupun sosial. Dalam memberikan dorongan moral kepada individu, agama selalu mengajak pemeluknya untuk berbuat baik, menjauhkan diri dari kejahatan dan hawa nafsu, mengejar keselamatan dan ketentraman di dunia maupun akhirat. Sedangkan secara sosial, agama sebagai cermin bagi terjadinya distorsi akhlak dan budi pekerti dalam masyarakat.

Agama, dengan demikian, menolak setiap tindakan yang dianggap bertentangan dengan cita-cita ideal di atas. Demikian halnya dengan kekerasan, mustahil agama mendorong para pemeluknya untuk bertindak dengan cara-cara kekerasan dan represif yang secara sosial dapat mengancam atau bahkan menyengsarakan orang lain. Karena hal ini tidak sesuai dengan 
karakter dan fitrah agama. Fitrah agama berkaitan dengan usaha manusia untuk berkomunikasi dengan sang pencipta, kesucian hidup, keluhuran moral, ketenangan dan kedamaian. Sedangkan pengrusakan, penjarahan, perampasan nyawa orang lain, intimidasi, jelas sangat bertentangan dengan jiwa agama (Yakin, 2009: 7-8).

Ragam kekerasan berbasis agama yang terjadi di tanah air, dalam hal ini teror-teror bom di Sari Club dan Peddy's Club Kuta Legian Bali, 12 Oktober 2002, bom di JW Mariot 5 Agustus 2003 yang menewaskan belasan orang dan luka-luka puluhan orang, kemudian disusul dengan kasus-kasus bom buku pertengahan Maret 2011, pengeboman yang terjadi di masjid April 2011 dan bom-bom yag meledak di tahun 2012 disertai serangkaian penangkapan dan penyergapan teroris oleh aparat dapat menjelma terjadinya "prahara nasional dan global", termasuk mewujudkan tragedi kemanusiaan, pengebirian martabat bangsa dan penyejarahan tragedi atas Hak Asasi Manusia (HAM). Hak Asasi Manusia (HAM) kehilangan eksistensinya dan tercerabut kesucian atau kefitrahannya di tangan pembuat teror (Wahid, 2004: 1).

Berangkat dari ragam konflik yang terjadi di Indonesia, sesungguhnya perlu adanya penerapan perdamaian di seluruh tataran masyarakat. Penerapan perdamaian dan pemahaman Islam secara utuh merupakan tanggung jawab bersama. Pesantren secara umum telah berperan dalam perdamaian, menjaga stabilitas dan mengakomodasi hubungan yang harmonis antara tradisi lokal dan nilai-nilai dari luar (Sholeh, 2007: 89-90). Juga perlu adanya program-progam seperti deradikalisasi untuk memberikan pandangan serta menekan perkembangan ideologi yang tidak benar dalam sebuah komunitas pesantren.

Sejalan dengan banyaknya gerakan-gerakan radikal berbasis agama, sesungguhnya pesantren sebagai komunitas yang lebih terfokus pada "tafakkuh fid dien" memiliki peran yang besar untuk mengantisipasi arus gerakan-gerakan radikal tersebut di masyarakat. Pada tataran normatif dan empiris pesantren memiliki konstribusi besar untuk memberikan pandangan, sikap serta alternatif untuk meminimalisir berkembangnya gerakan radikal agama, seperti terorisme diantaranya dengan menerapkan pendidikan peace building sebagai upaya antisipasif di kalangan masyarakat pesantren dan sekitarnya.

Pondok pesantren di Indonesia telah menghasilkan lulusan santri yang bertafaqquh fid dien memiliki keilmuan dibidang agama serta umum. Disamping itu, para santri di bekali dengan pembelajaran kitab terkait dengan akhlak, fiqih serta tasawuf, sehingga diharapkan dari pondok pesantren ini akan 
melahirkan generasi-generasi Islam yang mumpuni, mampu membendung arus radikalisme agama di tengah-tengah masyarakat Indonesia yang plural.

\section{Definisi, Faktor dan Bentuk-Bentuk Radikalisme}

Terminologi tentang "radikalisme" memang beragam, menurut Azyumardi Azra kata radikal, mengacu kepada keberadaan, orang atau gerakan tertentu yang menginginkan perubahan sosial dan politik secara cepat dan menyeluruh, dan tidak jarang dilakukan dengan menggunakan cara-cara tanpa kompromi dan bahkan kekerasan, bukan dengan cara-cara damai. Dengan demikian radikalisme keagamaan berhubungan dengan cara memperjuangkan keyakinan keagamaan yang dianutnya dengan tanpa kompromi dan bila perlu dilakukan dengan cara anarkisme dan kekerasan (Nuh, 2010: 1-2). Menurut Harun Nasution, yang dimaksud dengan radikalisme adalah gerakan yang berpandangan kolot dan sering menggunakan kekerasan dalam mengajarkan keyakinan mereka (Nasution, 1995: 124). Sementara Islam merupakan agama kedamaian yang mengajarkan sikap berdamai dan mencari perdamaian. Islam tidak pernah membenarkan praktek penggunaan kekerasan dalam menyebarkan agama, paham keagamaan serta paham politik.

Istilah radikalisme Islam berasal dari pers barat untuk menunjuk gerakan Islam garis keras (ekstrim, fundamentalis, militan). Istilah fundamentalisme dan radikalisme dalam prespektif Barat sering dikaitkan dengan sikap ekstrim, kolot, stagnasi, konservatif, anti-Barat, dan keras dalam mempertahankan pendapat bahkan dengan kekerasan fisik. Penggunaan istilah radikalisme atau fundamentalisme bagi umat Islam sebenarnya tidak tepat karena gerakan radikalisme itu tidak terjadi di setiap negeri muslim dan tidak dapat ditimpakan kepada Islam. Radikalisme merupakan gerakan yang dilakukan oleh individu atau kelompok yang dirugikan oleh fenomena sosio-politik dan sosio-historis.

Adapun faktor-faktor penyebab munculnya gerakan radikalisme adalah: Pertama, faktor-faktor sosial-politik. Gejala kekerasan "agama" lebih tepat dilihat sebagai gejala sosial-politik daripada gejala keagamaan. Dalam hal ini kaum radikalisme memandang fakta historis bahwa umat Islam tidak diuntungkan oleh peradaban global sehingga menimbulkan perlawanan terhadap kekuatan yang mendominasi. Dengan membawa bahasa dan simbol serta slogan-slogan agama kaum radikalis mencoba menyentuh emosi keagamaan dan menggalang kekuatan untuk mencapai tujuan "mulia" dari politiknya. Tentu saja hal yang demikian ini tidak selamanya dapat disebut memanipulasi agama karena sebagian 
perilaku mereka berakar pada interpretasi agama dalam melihat fenomena historis. Karena dilihatnya terjadi banyak penyimpangan dan ketimpangan sosial yang merugikan komunitas muslim maka terjadilah gerakan radikalisme yang ditopang oleh sentimen dan emosi keagamaan.

Kedua, faktor emosi keagamaan. Harus diakui bahwa salah satu penyebab gerakan radikalisme adalah faktor sentimen keagamaan, termasuk didalamnya adalah solidaritas keagamaan untuk kawan yang tertindas oleh kekuatan tertentu. Tetapi hal ini lebih tepat dikatakan sebagai faktor emosi keagamaanya, dan bukan agama (wahyu suci yang absolut) walaupun gerakan radikalisme selalu mengibarkan bendera dan simbol agama seperti dalih membela agama, jihad dan mati syahid. Dalam konteks ini yang dimaksud emosi keagamaan adalah agama sebagai pemahaman realitas yang sifatnya interpretatif. Jadi sifatnya nisbi dan subjektif.

Ketiga, faktor kultural ini juga memiliki andil yang cukup besar yang melatarbelakangi munculnya radikalisme, yang dimaksud faktor kultural di sini adalah sebagai antitesa terhadap budaya sekularisme. Budaya Barat merupakan sumber sekularisme yang dianggap sebagai musuh yang harus dihilangkan dari bumi. Sedangkan fakta sejarah memperlihatkan adanya dominasi Barat dari berbagai aspeknya atas negeri-negeri dan budaya muslim. Peradaban Barat sekarang ini merupakan ekspresi dominan dan universal manusia.

Barat telah dengan sengaja melakukan proses marjinalisasi seluruh sendi-sendi kehidupan muslim sehingga umat Islam menjadi terbelakang dan tertindas. Barat, dengan sekularismenya, sudah dianggap sebagai bangsa yang mengotori budaya-budaya bangsa Timur dan Islam, juga dianggap bahaya terbesar dari keberlangsungan moralitas Islam.

Keempat, faktor ideologis anti westernisme. Westernisme merupakan suatu pemikiran yang membahayakan muslim dalam mengaplikasikan syariat Islam. Sehingga simbol-simbol Barat harus dihancurkan demi penegakan syariat Islam. Walaupun motivasi dan gerakan anti-Barat tidak bisa disalahkan dengan alasan keyakinan keagamaan, tetapi jalan kekerasan yang ditempuh kaun radikalisme justru menunjukkan ketidakmampuan mereka dalam memposisikan diri sebagai pesaing dalam budaya dan peradaban.

Kelima, faktor kebijakan pemerintah. Ketidakmampuan pemerintah di negara-negara Islam untuk bertindak memperbaiki situasi atas berkembangnya frustasi dan kemarahan sebagian umat Islam disebabkan dominasi ideologi, militer maupun ekonomi dari negara-negara besar. Dalam hal ini elit-elit pemerintah di negeri-negeri muslim belum atau kurang dapat mencari akar 
yang menjadi penyebab munculnya tindak kekerasan (radikalisme) sehingga tidak dapat mengatasi problema sosial yang dihadapi umat.

Disamping itu, faktor media massa (pers) Barat yang selalu memojokkan umat Islam juga menjadi faktor munculnya reaksi dengan kekerasan yang dilakukan oleh umat Islam. Propaganda-propaganda lewat pers memang memiliki kekuatan dahsyat dan sangat sulit untuk di tangkis sehingga sebagian "ekstrim" yaitu perilaku radikal sebagai reaksi atas apa yang ditimpakan kepada komunitas muslim (Bahri, 2004: 3-8).

Radikalisme keagamaan pada awalnya tidak selalu muncul dari paham keagamaan tetapi lebih banyak muncul dari akibat perbedaan pandangan atau bahkan pertikaian politik. Baru kemudian menembus kepada paham keagamaan, dan selanjutnya agama dijadikan legitimasi untuk membenarkan tindakan agar mendapatkan dukungan, dan motivasi perjuangan.

Radikalisme keagamaan berhubungan dengan memperjuangkan keyakinan/paham keagamaan dengan drastis, tanpa kompromi, bahkan dengan kekerasan. Pengikut radikalisme keagamaan pada umumnya berasal dari; a) keluarga miskin yang mengalami kekecewaan karena merasa terpinggirkan dalam peran sosial-ekonomi dan politik; b) mereka yang memahami ajaran agama secara tekstual, tidak memahami konteks di mana sebuah teks keagamaan (al Quran dan hadits) itu turun; c) motto gerakannya adalah: pemurnian ajaran agama dalam ibadah dan budaya dan khilafah, dalam bidang politik ( Bahri, 2010: 140-141).

Gerakan radikalisme di Indonesia diantaranya dengan bentuk:

1. Bersifat transaksional berasal dari Timur Tengah. Berkembang pesat di awal era reformasi (sekitar tahun 1997 dan 1998), dengan nama yang beragam. Sampai sekarang menunjukkan adanya peningkatan secara kuantitatif maupun kualitatif.

2. Sasaran utamanya adalah generasi muda melalui kegiatan di sekolah, perguruan tinggi, dan rumah ibadah (masjid, surau, dan musholla). Bentuk kegiatannya antara lain: seminar (insidentil), taklim (rutin), siaran radio, buletin, pendirian pondok pesantren dan lembaga pendidikan formal.

Pondok pesantren dalam memandang isu gerakan radikal adalah: 1) radikalisme keagamaan tidak sesuai dengan pola pendidikan yang selama ini dijalankan oleh pesantren, hal ini juga bertentangan dengan budaya Islam Indonesia sebab Islam datang ke Indonesia bukan dengan kekerasan atau paksaan, melainkan dengan penuh kesantunan, tepo seliro dan kekeluargaan; 
2) radikalisme dapat mengganggu tatanan kehidupan keagamaan di Indonesia yang telah terjalin dengan penuh toleransi; 3) banyak orang yang berdalil al Quran dan hadits tetapi realitas amalannya tidak sesuai dengan doktrin agama. Ia hanya memahami tekstual sementara kontekstualnya diabaikan (Bahri, 2010: 132-133).

\section{Urgensi Pendidikan Peace Building dalam Komunitas Pesantren}

Membangun perdamaian di kalangan masyarakat yang plural adalah sebuah keniscayaan, karena masyarakat Indonesia yang beragam dalam hal ras, etnis, budaya dan agama juga dianggap rentan dalam menimbulkan konflik. Peace culture (budaya damai) bisa berarti budaya anti kekerasan (non-violence culture), yang secara konseptual dan tradisi dimiliki oleh Pesantren. Simon Fisher et al menggambarkan makna budaya anti kekerasan dengan:

(tradisi) tidak menggunakan kekerasan karena kekerasan tidak mencapai apa pun, dan kemungkinan besar akibatnya akan berupa penderitaan...(tradisi) anti kekerasan berusaha menjangkau dan menyadarkan hati nurani seluruh umat manusia yang terlibat, sambil bekerja secara aktif menghentikan atau mencegah perilaku desktruktif (Sholeh, 2007: xxxiv).

Pada dasarnya pesantren di bangun atas keinginan bersama dua komunitas yang saling bertemu yaitu komunitas santri yang ingin menimba ilmu sebagai bekal hidup dan kiai/guru yang secara ikhlas ingin menganjarkan ilmu dan pengalamannya. Relasi didaktik ini saling melengkapi. Kiai dan santri adalah dua entitas yang memiliki kesadaran yang sama untuk secara bersama-sama membangun komunitas keagamaan yang disebut pesantren. Kiai, ustadz, dan santri hidup di satu kampus (keluarga besar) berlandaskan nilai-nilai agama Islam yang dilengkapi dengan norma-norma dan kebiasaan-kebiasaan sendiri. Komunitas keagamaan pesantren dilandasi oleh keinginan bertafaqquh fi al dien (mendalami/mengkaji agama) dengan kaidah al muhafazhah 'ala al qadim al shalih wa al akhdz bi al jadid al ashlah (memelihara tradisi lama yang baik dan mengambil tradisi baru yang lebih baik). Keinginan dan kaidah ini merupakan nilai pokok yang melandasi kehidupan dunia pesantren. Suatu bentuk faslsafah yang cukup sederhana, tetapi mampu mentransformasikan potensi dan menjadikan diri pesantren sebagai agent of change bagi masyarakat. Sehingga eksistensi pesantren identik dengan/dikategorikan sebagai lembaga pengembangan masyarakat.

Selain dua nilai diatas, eksistensi pesantren menjadi kokoh karena dijiwai oleh apa yang dikenal dengan panca-jiwa pesantren. Pertama, jiwa 
keikhlasan yaitu jiwa kepesantrenan yang tidak didorong oleh ambisi apa pun untuk memperoleh keuntungan-keuntungan tertentu khususnya secara material, melainkan semata-mata karena beribadah kepada Allah. Jiwa keikhlasan memanifestasi ke dalam segala rangkaian sikap dan perilaku serta tindakan yang dilakukan secara ritual oleh komunitas pesantren. Jiwa keikhlasan ini dilandasi oleh keyakinan bahwa perbuatan baik pasti diganjar oleh Allah SWT dengan yang baik pula dan bahkan berkali lipat. Kedua, jiwa kesederhanaan. Kata 'sederhana' di sini bukan berarti pasif, melarat, miskin dan menerima apa adanya, tetapi mengandung unsur kekuatan dan ketabahan hati, kemampuan mengendalikan diri, dan kemampuan menguasai diri dalam menghadapi kesulitan. Di balik jiwa kesederhanaan ini tersimpan jiwa yang besar, berani, maju, dan pantang menyerah dalam menghadapi dinamika sosial secara kompetitif. Jiwa kesederhanaan ini menjadi 'baju' identitas yang paling berharga bagi sivitas santri dan kiai. Ketiga, jiwa bebas. Jiwa yang bebas ini mengandaikan sivitas pesantren sebagai manusia yang kokoh dalam memilih jalan hidup dan masa depannya dengan jiwa besar dan sikap optimis menghadapi segala problematika kehidupan dengan nilai-nilai Islam. Kebebasan di sini juga berarti sikap kemandirian yang tidak berkenan di dikte oleh pihak luar dalam membangun orientasi sisten kepesantrenan dan kependidikan. Keempat, jiwa ukhuwah Islamiyah. Jiwa ukhuwah Islamiyah ini memanifestasi dalam keseharian sivitas pesantren yang bersifat dialogis, penuh keakraban, penuh kompromi, dan toleransi. Jiwa ini mematri suasana yang damai, sejuk, senasib, saling membantu, dan saling menghargai bahkan saling men-support dalam pembentukan dan pengembangan idealisme santri.

Sejumlah nilai diatas menjadikan pesantren eksis sepanjang sejarah kehidupan dan dinamika zaman. Globalisasi teknologi-indrutri yang mendunia tidak menggoyahkan eksistensi pesantren sebagai penjaga dan sekaligus pelestari nilai-nilai. Kenapa demikian? Karena pesantren hanya bergantung kepada kebenaran relatif yang bercorak empiris dan pragmatis untuk memecahkan pelbagai persoalan kehidupan sesuai hukum agama. Artinya semua aktivitas dunia pesantren selalu mengacu kepada kehidupan duniawi dan ukhrawi secara seimbang dan sinambung. Kepercayaan dan keimanan sivitas pesantren senantiasa layak diteladani bagi pengembangan masyarakat secara menyeluruh.

Nilai kemandirian sebagai pondasi eksistensial pesantren merupakan nilai utama yang paling signifikan bagi perubahan sosial (sosial change) dan budaya yang otonom (autonomous culture). Pesantren dengan kemandiriannya 
itu telah banyak memainkan peran sebagai creative cultural makers dan kiai menjadi sangat penting dalam kehidupan masyarakat. Sehingga eksistensi kiai selaku pengasuh pesantren sekaligus tokoh masyarakat-seperti dikatakan Clifford Geertz- sebagai mediator dan pialang (cultural broker). Kenyataan ini diakui oleh karena kiai dengan integritas keilmuan tinggi mampu memproteksi kesadaran masyarakatnya sehingga terbentuk komunitas keagamaan (religious community) dan budaya yang mandiri. Karena nilai kemandirian ini pulalah pesantren menjadi lepas dari jeratan ketergantungan (dependency) terhadap pemerintah dan hegemoni apa pun (Sholeh, 2007: 54-57).

Lembaga pesantren berdasarkan UU Nomor 20 Tahun 2003 tentang Sistem Pendidikan Nasional telah menjadi bagian dari sistem pendidikan nasional. Pesantren memiliki kesempatan meningkatkan perannya dalam rangka mencerdaskan bangsa seperti yang dirumuskan dalam tujuan sisdiknas "mengembangkan kemampuan dan membentuk watak serta peradaban bangsa yang bermartabat dalam rangka mencerdaskan kehidupan bangsa, mengembangkan potensi peserta didik agar menjadi manusia yang beriman dan bertakwa kepada Tuhan Yang Maha Esa, berakhlak mulia, sehat, berilmu, cakap, kreatif, mandiri, dan menjadi warga negara yang demokratis serta bertanggung jawab". UU No 20 Tahun 2003 telah menetapkan prinsip penyelenggaraan pendidikan yang demokratis dan berkeadilan serta tidak diskriminatif dengan menjunjung tinggi hak asasi manusia, nilai keagamaan, nilai kultural, dan kemajemukan bangsa (TM, 2007: 16).

Dari berbagai peran diatas, sesungguhnya pesantren memiliki konstribusi besar dalam upaya membangun peace building melalui penerapan nilai-nilai keagamaan, nilai-nilai kultural dan demokrasi yang ditandai dengan upaya-upaya toleransi terhadap pemeluk agama lain, terhadap orang yang berbeda aliran agamanya dan dalam memahami kehidupan keberagamaan di masyarakat.

\section{Model Membangun Peace Building di Pesantren}

Adapun model membangun Peace Building di pesantren adalah sebagai berikut:

1. Pimpinan pondok pesantren memberikan teladan berupa prilaku yang mencerminkan pelaksanaan ajaran Islam yang cinta damai. Secara kelembagaan, pondok pesantren memiliki peran strategis, dapat memajukan dinamika sosial masyarakat yang heterogen, menjadi suatu sistem tatanan yang kondusif. Seorang kiai sebagai leader (tokoh sentral) di pesantren cukup banyak memberikan konstribusi pemikiran 
dalam perkembangan sikap keberagamaan secara massive, dan bisa dirasakan pengaruhnya dalam kehidupan keberagamaan kita. Kiai dalam hal ini sebagai pemimpin pondok pesantren memiliki peran besar untuk memberikan teladan dan akhlak yang baik kepada umat. Karena selama ini pendidikan pesantren menekankan keshalehan, baik spiritual maupun sosial, dengan keteladanan perilaku kiai. Dikarenankan kiai dan pengasuh merupakan figur sentral dan model sentral yang diikuti oleh santri/umat. Memberikan pemahaman kepada santri tentang nilai-nilai perdamaian, persaudaraan, penyelamatan, dan cinta kasih, selain itu perlu pula ditingkatkan akan kesadaran hukum, penegakan keadilan, toleran terhadap perbedaan dan moderasi dalam memandang berbagai permasalahan. Dalam hidup bermasyarakat, contohnya komunitas pesantren akan selalu di hadapkan pada banyak perbedaan, mulai perbedaan ras, jenis kelamin, hingga pikiran serta kemauan dari individu masing-masing santri maupun pengasuh serta pengajar. Hal yang selalu di lakukan para pengasuh adalah, ketika akan memberikan sebuah tata tertib baru terkait dengan persoalan pondok, maka pengasuh selalu meminta pertimbangan kepada dewan pengasuh lainnya, kemudian di teruskan kepada pengurus pondok pesantren untuk selanjutnya di terapkan kepada para santri, seperti adanya buku Muhasabah diri santri. Semata-mata adanya buku kontrol itu untuk memonitoring kegiatan santri agar berdisiplin dan sadar hukum, karena apabila mereka belum dan tidak menghafal salah satu materi yang harus di hafal, maka para santri mendapatkan sangsi, begitu pula apabila menghafal maka kan mendapatkan hadiah (reward) sesuai dengan poin yang sudah di tentukan. Dari sinilah juga santri akan belajar untuk mengatur dan mengintrospeksi dirinya. Selain itu juga tausiyah dari para pengasuh dan pengajar di pondok juga menekankan kepada pentingnya bersosialisasi antar penghuni pondok pesantren dengan baik, harus bersikap adil dan berakhlaqul karimah. Keberagamaan dapat dikembangkan melalui proses pemahaman, sikap, aplikasi dan pembelajaran. Dengan menanamkan sikap toleransi pada setiap santri sehingga tidak memicu sikap radikal.

2. Meningkatkan kemandirian santri dengan memberikan keterampilan kewirausahaan, karena keterhimpitan ekonomi menjadi celah yang bisa dimanfaatkan oleh kelompok radikal. Kegiatan untuk melatih kemandirian dapat diberikan di sela-sela kegiatan belajar santri, sehingga Secara tidak 
langsung, ini merupakan cara mudah bagi pondok pesantren dalam mengidentifikasi para alumninya, memonitoring kegiatan-kegiatan para santri setelah lulus belajar di pondok pesantren dan diharapkan kelak ketika santri telah kembali ke tengah-tengah masyarakat mereka memiliki bekal untuk mandiri di bidang ekonomi, sehingga santri dapat berdaya dan tidak mudah terseret dan meminimalisasi para santri untuk dimanfaatkan dalam beragam tindakan radikalisasi agama.

3. Membudayakan sharing pendapat dengan santri dan masyarakat sehingga terbentuk pemahaman komprehensif yang lebih menonjolkan pada nilainilai Islam yang penuh kemoderatan dan persaudaraan. Budaya sharing idea, adalah budaya musyawarah untuk mencari sebuah solusi. Sikap ini perlu di kembangkan di kalangan pesantren, baik antar pengasuh maupun para pengajar dengan para santri. Hal ini dimaksudkan agar dalam sebuah permasalahan menjadi jelas, tidak timbul wacana baru yang tidak sesuai dengan penyelesaian masalah tersebut.

4. Mengembangkan pengajaran agama yang humanis bagi kaum muda non pesantren dan masyarakat luas.

5. Islam dan umat Islam saat ini menghadapi paling tidak dua tantangan: pertama, kecenderungan sebagaian kalangan umat Islam untuk untuk bersikap ekstrim dan ketat dalam memahami hukum-hukum agama dan mencoba memaksakan cara tersebut di tengah masyarakat muslim, bahkan dalam beberapa hal menggunakan kekerasan. Kedua, kecenderungan lain yang juga ekstrim dengan bersikap longgar dlam beragama dan tunduk pada perilaku serta pemikiran negatif yang berasal dari budaya dan peradaban lain. Kecenderungan pertama boleh jadi lahir karena melihat kenyataan Islam dan umat Islam saat ini yang berda dalam kemunduran dan keterbelakangan di segala bidang. Karena itu untuk meraih kebangkitan dan kejayaan seperti yang pernah dicapai generasi terdaulu dapat dilakukan dengan cara kembali kepada generasi terdahulu (al salaf al shalih). Dalam upayanya itu mereka mengutip teks-teks keagamaan (al Quran dan Hadits) dan karya-karya ulama klasik (turats) sebagai landasan dan kerangka pemikiran, tetapi dengan memahaminya secara tekstual terlepas dari konteks kesejarahan. Sehingga tak ayal mereka hidup tampak seperti "generasi yang terlambat lahir", sebab hidup di tengah masyarakat modern dengan cara berpikir generasi terdahulu. Mereka tidak sadar bahwa zaman selalu berkembang dan telah berubah. Islam pun tampak sebagai ajaran yang eksklusif, jumud dan tidak bisa 
sejalan dengan modernitas. Di sisi lain, semangat untuk mengedepankan Islam sebagai agama yang selalu sejalan dengan perkembangan ruang dan waktu telah mendorong sejumlah kalangan untuk mengimpor berbagai pandangan dan pemikiran dari budaya dan peradaban asing yang saat ini didominasi oleh pandangan materialistik. Bahkan tidak jarang dilakukan dengan mengorbankan teks-teks keagamaan melalui penafsiran kontekstual.

Kedua sikap diatas tidak menguntungkan Islam dan umat Islam. Kecenderungan pertama telah memberikan citra negatif kepada Islam dan umat Islam sebagai agama dan komunitas masyarakat yang eksklusif dan mengajarkan kekerasan dalam dakwahnya. Sementara kecenderungan kedua telah mengakibatkan Islam kehilangan jati dirinya karena lebur dan larut dalam budaya dan perdaban lain. Yang pertama terlalu ketat bahkan cenderung menutup diri dalam sikap keberagamaan, dan yang kedua terlalu longgar dan terbuka sehingga mengaburkan esensi ajaran agama itu sendiri. Kedua sikap ini tentu bertentangan dengan karakteristik umat Islam yang dalam surat al Baqarah ayat 143 disebut sebagai ummatan wasathan dengan pengertian tengahan, moderat, adil dan terbaik. Sikap wassath ini diperolah karena ajaran yang dianutnya bercirikan wasathiyyah (Hanafi, 2010:71-72).

Wasathiyyah (moderasi) ajaran Islam tersermin antara lain dalam hal-hal berikut:

\section{Akidah}

Akidah Islam sejalan dengan fitrah kemanusiaan, berada di tengah antara mereka yang tunduk pada khurafat dan mempercayai segala sesuatu walau tanpa dasar dan mereka yang mengingkari segala sesuatu yang berwujud metafisik. Selain mengajak beriman kepada yang ghaib, Islam mengajak akal manusia untuk membuktikan ajakannya secara rasional. Qul haatu burhaanakum in kuntum shadiqiin (QS al Baqarah: 111).

2. Ibadah dan syiar agama

Islam mewajibkan penganutnya untuk melakukan ibadah dalam bentuk dan jumlah yang sangat terbatas, misalnya shalat lima kali dalam sehari, puasa sebulan dalam setahun, haji sekali seumur hidup, agar selalu ada komunikasi antara manusia dengan Tuhannya. Selebihnya Allah mempersilahkan manusia untuk berkarya dan bekerja mencari rizki Allah di muka bumi. Kewajiban melaksanakan ibadah tidak banyak dan menyulitkan, juga tidak menghalangi seseorang untuk bekerja mencari nafkah. Moderasi dalam peribadatan ini tercermin sangat jelas dalam firman Allah: 
"Hai orang-orang yang beriman, apabila diseru utnuk menunaikan shalat Jum'at maka bersegeralah kamu kepada mengingat Allah dan tinggalkanlah jual beli. Yang demikian itu lebih baik bagimu jika kamu mengetahui. Apabila telah ditunaikan shalat, maka bertebaranlah kamu di muka bumi; dan carilah karunia Allah dan ingatlah Allah sebanyak-banyaknya supaya kamu beruntung" (QS al Jumuah: 9-10).

Jika datang waktu shalat Jum'at tinggalkanlah seluruh aktifitas dagang, dan bilamana salat usai maka lanjutkanlah aktifitas berdagang dengan tujuan memperoleh karunia Allah dan senantiasa ingat akan Allah agar mendapat keberuntungan di dunia dan akhirat.

3. Akhlak

Dalam pandangan al Quran manusia terdiri dari dua unsur; ruh dan jasad. Dalam proses penciptaan manusia pertama (Adam) dijelaskan bahwa Allah telah menciptakannya dari tanah kemudian meniupkan ke dalam tubuhnya ruh.

"(ingatlah) ketika Tuhanmu berfirman kepada malaikat: "Sesungguhnya aku akan menciptakan manusia dari tanah. Maka apabila telah Kusempurnakan kejadiannya dan Kutiupkan kepadanya roh (ciptaan)Ku; Maka hendaklah kamu tersungkur dengan bersujud kepadaNya"(QS Shad: 71-72).

Kedua unsur itu memiliki hak yang harus dipenuhi. Keseimbangan (tawazun) ini bukan hanya berlaku dalam sikap keberagamaan, tetapi di alam raya ini juga berlaku prinsip keseimbangan (Hanafi, 2010:71-79).

Oleh karena itu, Pondok Pesantren diharapkan dapat berkonstribusi dalam konsep wasathiyyah ini, melalui berbagai kegiatan pengajian dan halaqah rutin yang di selenggarakan, dengan maksud turut memberikan kemaslahatan umat dengan cara yang moderat, adil dan bijaksana, tidak ketat dan longgar (seimbang) dalam memahami teks-teks keagamaan.

\section{Simpulan}

Fakta empiris yang memperlihatkan banyak kasus konflik selalu diikuti oleh tindakan kekerasan memberi fondasi terhadap pentingnya pendidikan perdamaian (peace education). Pesantren sebagai wadah menggembleng generasi muslim perlu melakukan transfer perdamaian sebagai wujud Islam sebagai rahmatan lil 'alamin, baik kepada sesama muslim dan masyarakat. Sehingga tidak ada lagi kasus konflik yang dimotori oleh pesantren. Pemahaman Islam yang utuh membuat komunitas pesantren selalu menebarkan nilai-nilai kemanusiaan dan perdamaian. 


\section{Daftar Pustaka}

Bahri, Syamsul. 2004. Islam dan Wacana Radikalisme Agama Kontemporer. Jurnal Dinika. Volume 3. Nomor 1.

Bahri. 2010. Peranan Pesantren Dalam Mengembankan Budaya Damai. Dalam Hanafi, Mukhlis. Konsep Wasathiyah Dalam Islam. Jakarta: Puslitbang Kehidupan Keagamaan. Kementerian Agama RI.

Bahri. 2010. Peranan Pesantren Dalam mengembangkan Budaya Damai. Dalam Madjid, Abdul. Memahami Agama Damai Dunia Pesantren. Jakarta: Puslitbang Kehidupan Keagamaan. Kementerian Agama RI.

Bahri. 2010. Peranan Pesantren Dalam Mengembangkan Budaya Damai. Dalam Syawaluddin. Peranan Pengasuh Pondok Pesantren Dalam Mengembangkan Budaya Damai Di Provinsi Gorontalo. Jakarta: Puslitbang Kehidupan Keagamaan. Kementerian Agama RI.

Haidar, M. Ali. 2006. Diversifikasi Peran Kiai Sebagai Pendidik Di Pesantren. Jurnal Penelitian Pendidikan Agama dan Keagamaan. Volume 4. Nomor 3.

M. Nuh, Nuhrison. 2010. Peranan Pesantren Dalam Mengembangkan Budaya Damai. Badan Litbang dan Diklat Kementerian Agama. Jakarta: Maloho Jaya Abadi Press.

Nasution, Harun. 1995. Islam Rasional. Bandung: Mizan.

Sholeh, Badrus. 2007. Budaya Damai Komunitas Pesantren, Antara Konflik dan Perdamaian. Jakarta: Pustaka LP3ES Indonesia.

TM, Fuaduddin. 2007. Diversifikasi Pendidikan Pesantren: Tantangan dan Solusi. Jurnal Edukasi. Volume 5. Nomor 4. Puslitbang Pendidikan Agama dan Keagamaan Badan Litbang dan Diklat Depag RI.

Wahid, Abdul, dkk. 2004. Kejahatan Terorisme Prespektif Agama, HAM dan Hukum. Bandung: PT. Refika Aditama.

Yakin, Haqqul. 2009. Agama dan Kekerasan Dalam Transisi Demokrasi di Indonesia. Yogyakarta: eLSAQ Press. 